\title{
UPQC for Power Quality Improvement in DG Integrated Smart Grid Network: a Review
}

\author{
Shafiuzzaman Khadem \\ Technological University Dublin \\ Malabika Basu \\ Technological University Dublin, mbasu@tudublin.ie \\ Michael Conlon \\ Technological University Dublin, michael.conlon@tudublin.ie
}

Follow this and additional works at: https://arrow.tudublin.ie/engscheleart2

Part of the Electrical and Computer Engineering Commons

\section{Recommended Citation}

Khadem, S., Basu, M. \& Conlon, M. (2012). UPQC for Power Quality Improvement in DG Integrated Smart Grid Network: a Review. International Journal of Emerging Electrical Power Systems, vol.13, no.1, article 3. doi:10.1515/1553-779X.2878

This Article is brought to you for free and open access by the School of Electrical and Electronic Engineering at ARROW@TU Dublin. It has been accepted for inclusion in Articles by an authorized administrator of ARROW@TU Dublin. For more information, please contact arrow.admin@tudublin.ie, aisling.coyne@tudublin.ie, gerard.connolly@tudublin.ie.

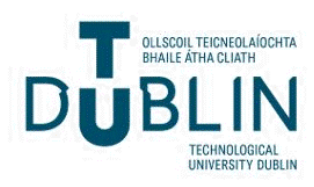




\section{International Journal of Emerging Electric Power Systems}

Volume 13, Issue 1 2012

Article 3

\section{UPQC for Power Quality Improvement in DG Integrated Smart Grid Network - A Review}

Md Shafiuzzaman K. Khadem Mr, Dublin Institute of Technology, Ireland

Malabika Basu, Dublin Institute of Technology, Ireland Michael F. Conlon, Dublin Institute of Technology, Ireland

Recommended Citation:

Khadem, Md Shafiuzzaman K. Mr; Basu, Malabika; and Conlon, Michael F. (2012) "UPQC for Power Quality Improvement in DG Integrated Smart Grid Network - A Review," International Journal of Emerging Electric Power Systems: Vol. 13: Iss. 1, Article 3.

DOI: $10.1515 / 1553-779 X .2878$

C2012 De Gruyter. All rights reserved. 


\title{
UPQC for Power Quality Improvement in DG Integrated Smart Grid Network - A Review
}

\author{
Md Shafiuzzaman K. Khadem Mr, Malabika Basu, and Michael F. Conlon
}

\begin{abstract}
Quality of power supply has become an important issue with the increasing demand of Distributed Generation (DG) systems either connected to the grid through some power electronics grid-tie inverters or to work in isolated (microgrid) mode towards the development of a smart grid network. In this paper a technical review of Integration of Unified Power Quality Conditioner (UPQC) in Distributed Generation Network has been presented. Though the primary task of UPQC is to minimize the grid voltage and load current disturbance along with the reactive and harmonic power compensation, additional functionalities like compensation of voltage interruption and active power transfer to the load and grid have also been identified. Connection methodologies with their pros and cons are also described. Recent improvements in capacity expansion techniques and future trends for the application of UPQC to cope up with the expanding DG capacity are also reviewed.
\end{abstract}

KEYWORDS: unified power quality conditioner, distributed generation, smart grid, microgrid, power quality 


\section{INTRODUCTION}

Quality of power supply has become an important issue with the increasing demand of DG systems either connected to the conventional grid, smart grid or microgrid. The need for monitoring of desired power quality in transmission levels as well as in low voltage distribution levels are increasing due to better customer service demand, reasonably priced meters, telecommunication development, network planning, operation and regulation requirements [1], which are also very important for the implementation of a smart grid distribution network. According to the IEC - International Electrotechnical Commission, "Smart Grid is the concept of modernizing the electric grid. The Smart Grid is integrating the electrical and information technologies in-between any point of Generation and any point of Consumption" [2]. The National Institute of Standards and Technology (NIST) has also developed the Smart Grid Conceptual Model, as shown in Figure 1, which provides a high-level framework for the smart grid that defines seven important domains: Bulk Generation, Transmission, Distribution, Customers, Operations, Markets and Service Providers [3] where power quality has been considered as an important component in the Smart Grid Network, as shown in Table 1.

Implementation of Custom Power Devices (CPD) like UPQC in DG or microgrid systems to improve the power quality is gaining greater importance [48]. This paper deals with the review of research work that has been completed so far on this issue. Emphasis has been given on integration techniques of UPQC in DG or microgrid system along with their advantages and disadvantages. Again, the number of DG systems like Photovoltaic and Wind Energy Systems are now penetrating more into the grid or microgrid as well as the numbers of non-linear loads are also increasing. Therefore, current research on capacity enhancement techniques of UPQC to cope up with the expanding DG or microgrid system is also reviewed.

\section{POWER QUALITY PROBLEMS IN DG INTEGRATED NETWORK}

Electric power is the result of a production process and according to the Council of European Energy Regulators (CEER) [9] the quality of electric power supply should comprise in three main areas, shown in Figure 2, where the power quality means the continuity of supply and voltage quality. Again, Green House Gas (GHG) emission and the Global Warming are the side effects of the conventional electric power production process. Therefore, developed countries are also trying to reduce their overall GHG emission by introducing and increasing the share of renewable energy into their electric grid system. Hence, the quality of power supply has become an important issue with the high penetration of DG systems 
either connected to the grid or microgrid. As the solar, wind, micro-hydro are the most leading sources of DG systems therefore power quality problems related to these DG system along with diesel (one of the highest $\mathrm{CO}_{2}$ emitter) have been identified and shown in Table 2.

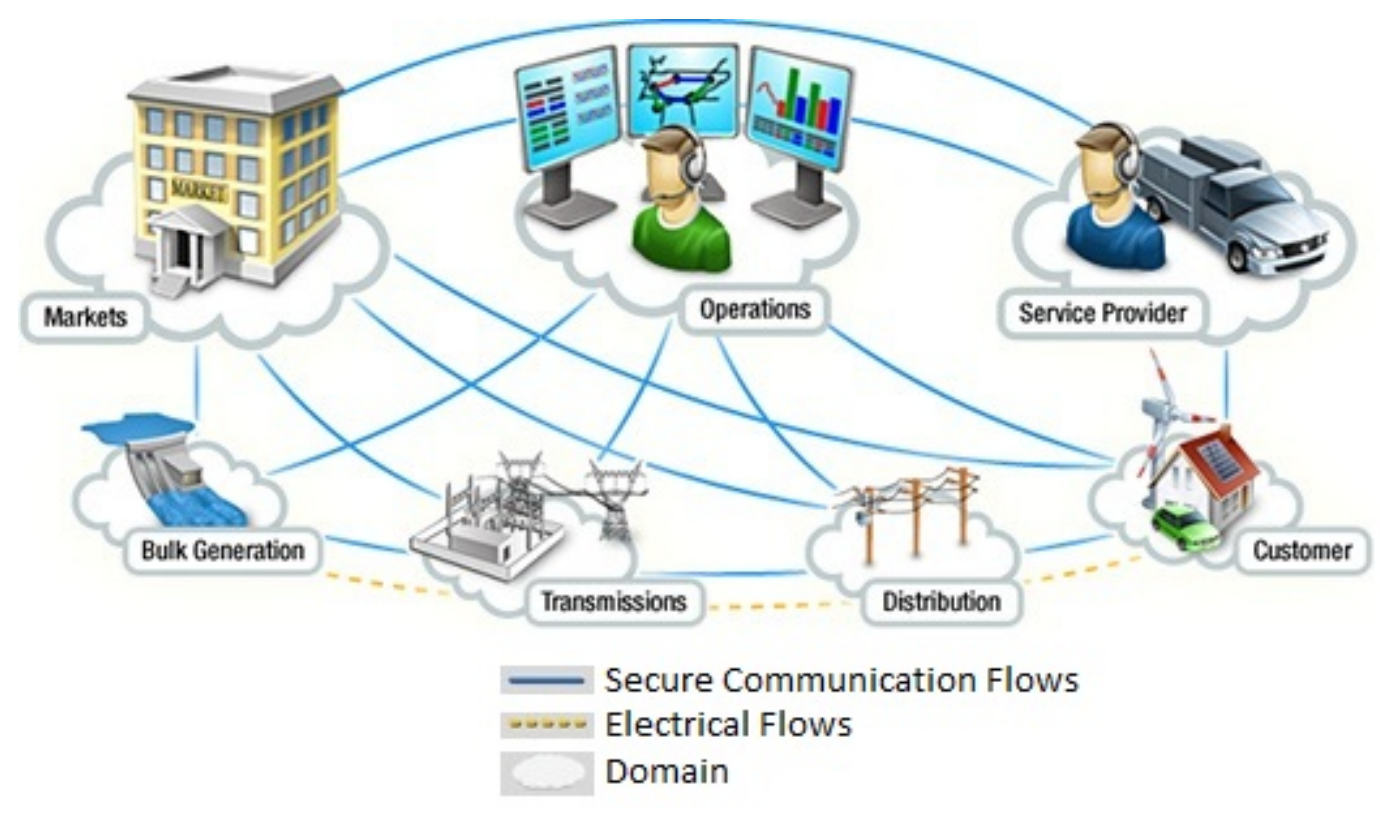

Figure 1 - Conceptual model of Smart Grid [3]

Table 1 - Components of Smart Grid Network

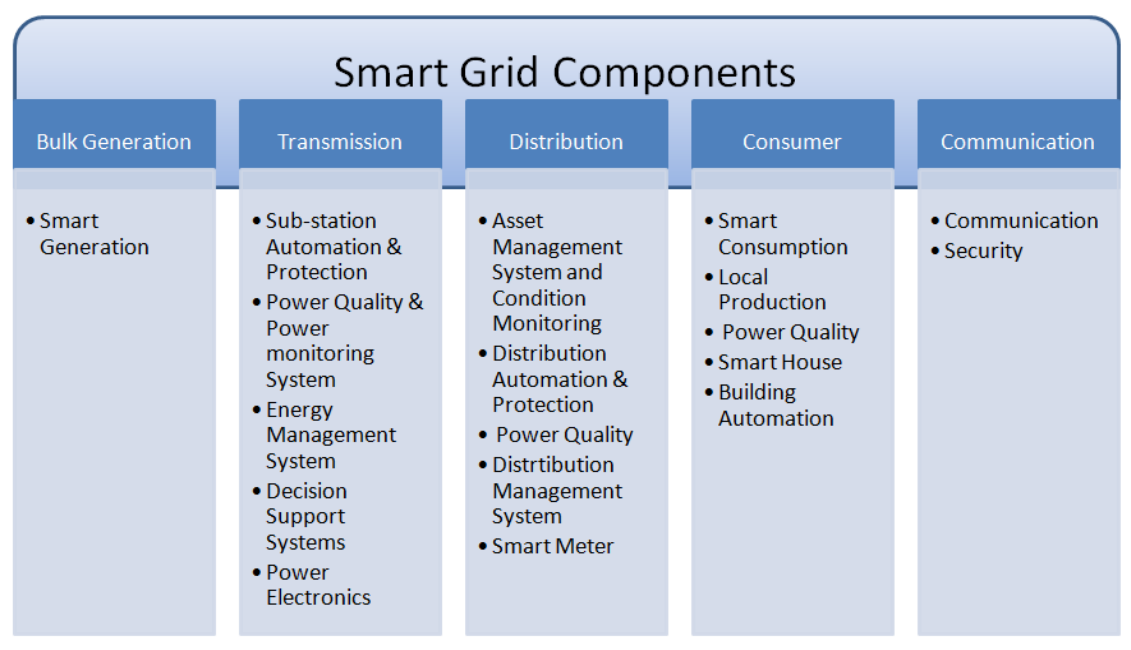


Khadem et al.: UPQC for DG Integrated Smart Grid Network - A Review

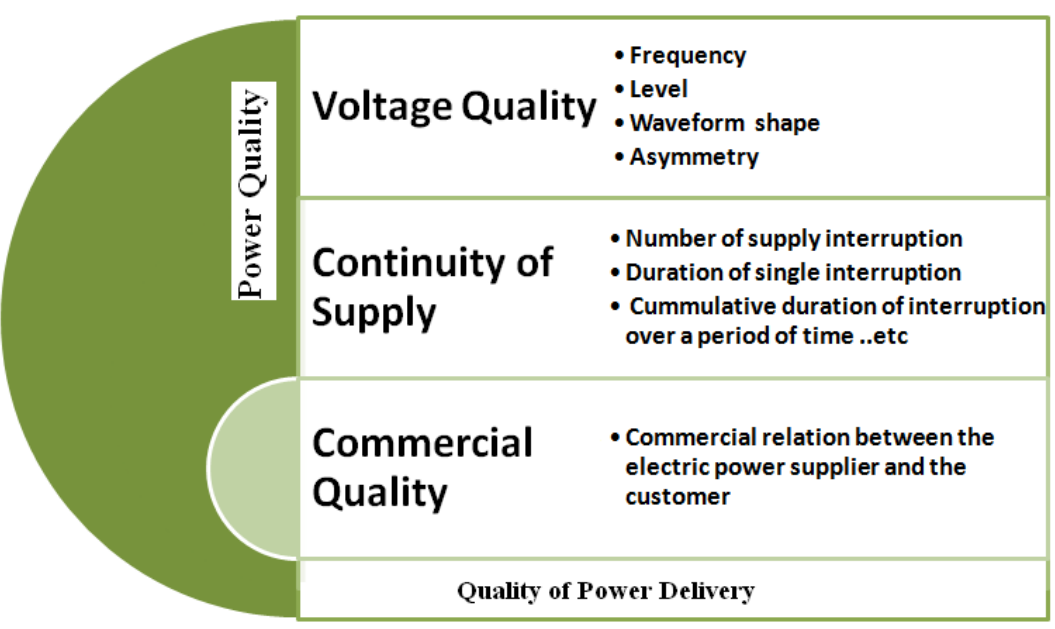

Figure 2 - Quality of Electric Power Supply

Table 2 - PQ problems related to DG systems

\begin{tabular}{|l|c|c|c|c|}
\hline \multicolumn{1}{|c|}{ PQ Problems } & $\begin{array}{c}\text { Wind } \\
\text { Energy }\end{array}$ & $\begin{array}{c}\text { Solar } \\
\text { Energy }\end{array}$ & $\begin{array}{c}\text { Micro/ } \\
\text { Small } \\
\text { Hydro }\end{array}$ & Diesel \\
\hline Voltage Sag/Swell & $\bullet$ & & $\bullet$ & $\bullet$ \\
\hline Over/Under Voltage & $\bullet$ & & & $\bullet$ \\
\hline Voltage Unbalance & & $\bullet$ & & \\
\hline Voltage Transient & $\bullet$ & & & \\
\hline Voltage Harmonics & $\bullet$ & $\bullet$ & $\bullet$ & \\
\hline Flicker & $\bullet$ & $\bullet$ & & $\bullet$ \\
\hline Current Harmonics & $\bullet$ & $\bullet$ & $\bullet$ & \\
\hline Interruption & $\bullet$ & $\bullet$ & \\
\hline
\end{tabular}

\section{WORKING PRINCIPLE OF UPQC}

UPQC is the integration of series (APFse) and shunt (APFsh) active power filters, connected back-to-back on the dc side, sharing a common DC capacitor [10], shown in Figure 3. The series component of the UPQC is responsible for mitigation of the supply side disturbances: voltage sags/swells, flicker, voltage unbalance and harmonics. It inserts voltages so as to maintain the load voltages at a desired level; balanced and distortion free. The shunt component is responsible for mitigating the current quality problems caused by the consumer: poor power factor, load harmonic currents, load unbalance etc. It injects currents in the ac 
system such that the source currents become balanced sinusoids and in phase with the source voltages. The overall function of UPQC mainly depends on the series and shunt APF controller. A basic functional block diagram of a UPQC controller is shown in Figure 4. Here, the shunt APF injects the compensating reactive and harmonic current using hysteresis current controller and where as the series APF uses PWM voltage controller to minimize the voltage disturbances.

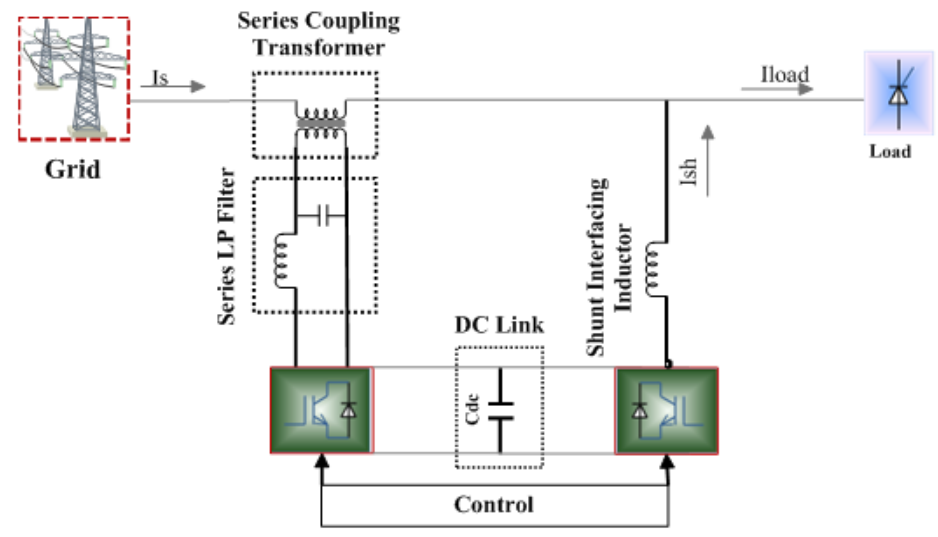

Figure 3 - Basic System Configuration of UPQC

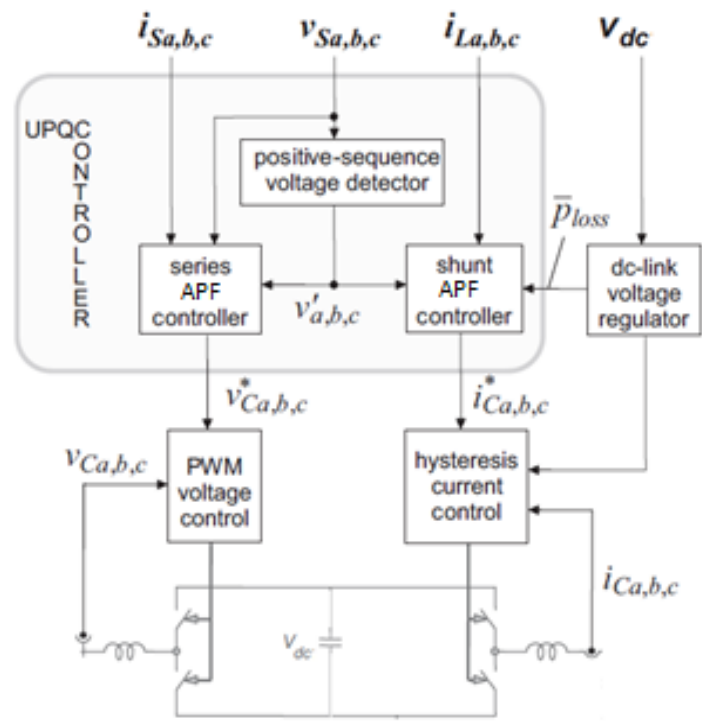

Figure 4 - Functional block diagram of a UPQC controller 


\section{INTEGRATION OF UPQC}

Recent reports $[4-8,11,12]$ show that significant research and development has been carried out on the application of UPQC to DG integrated network. As the UPQC can compensate for almost all existing PQ problems in the transmission and distribution grid, placement of a UPQC in the distributed generation network can be multipurpose. As a part of integration of UPQC in DG systems, research has been done on the following two techniques: DC-Linked and Separated DGUPQC systems.

\section{A. $(D G-U P Q C)_{D C-l i n k e d}$}

A structure has been proposed in [4-7], as shown in Figure 5, where DG sources are connected to a DC link in the UPQC as an energy source. This configuration works both in interconnected and islanded mode (shown in Figure 6). In Interconnected mode, DG provides power to the source and loads whereas in islanded mode DG (within its power rating) supplies the power to the load only. In Addition, UPQC has the ability to inject power using DG to sensitive loads during source voltage interruption. The advantage of this system is voltage interruption compensation and active power injection to the grid in addition to the other normal UPQC abilities. The system's functionality may be compromised if the DG resources are not sufficient during the voltage interruption conditions. Economical operation of the system can also be achieved by proper controlling of the active power transfer between the supply and DG source through a series APF [7]. The proposed system can also reduce the investment cost by nearly one fifth if the UPQC and DG are used separately [8].

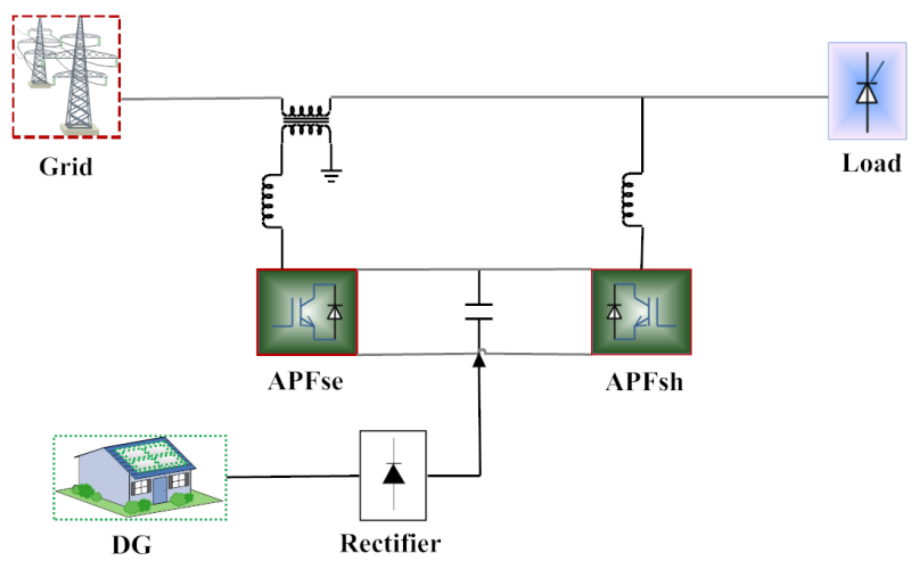

Figure 5 - UPQC with DG connected to the DC link 


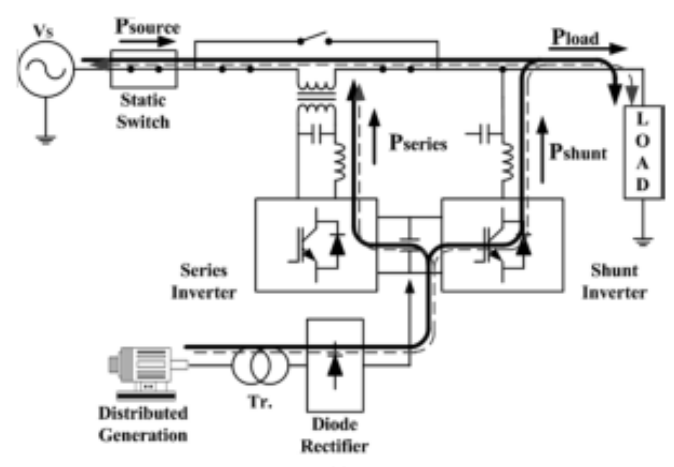

(a)

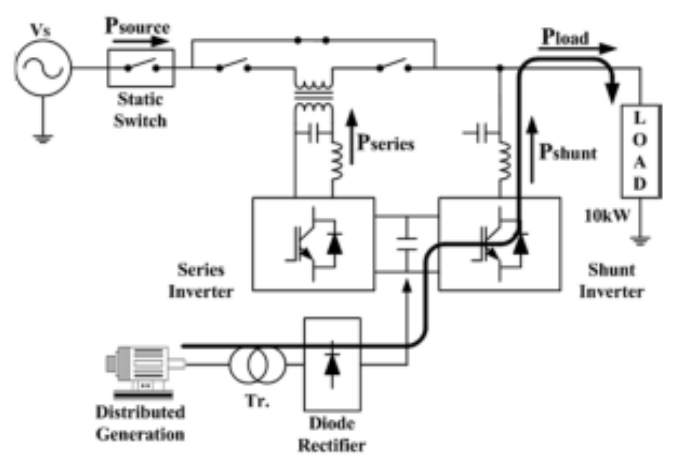

(b)

Figure 6 - (DG-UPQC) $)_{\text {DC-linked }}$ System operation concept (a) Interconnected mode; (b) Islanding mode [4]

B. $(U P Q C-D G)_{\text {Separated }}$

A typical application of a UPQC might be to overcome the grid integration problems of the DG, such as the fixed-speed induction generator (FSIG) as investigated in [11] and shown in Figure 7. The FSIG fails to remain connected to the grid in the event of a grid voltage dip or line fault due to excessive reactive power requirement. The drop in voltage creates over-speeding of the turbine, which causes a protection trip. With the aid of the UPQC, this fault-ride-through capability is achieved, which greatly enhances system stability. Results show (Figure 8) that the UPQC is one of the best devices for the integration of wind energy system to the grid. In the case of a wind farm connected to a weak grid, UPQC can also be placed at the PCC to overcome voltage regulation problems [12]. In these separated systems, the series APF of the UPQC is placed near the DG side to conduct the voltage regulation by injecting the voltage in phase with PCC voltage. This type of UPQC is referred to as left shunt UPQC [13]. Based on the research study, in addition to the normal functionality of UPQC, some of the other advantages and disadvantages have been identified for the techniques which are given in Table 3 .

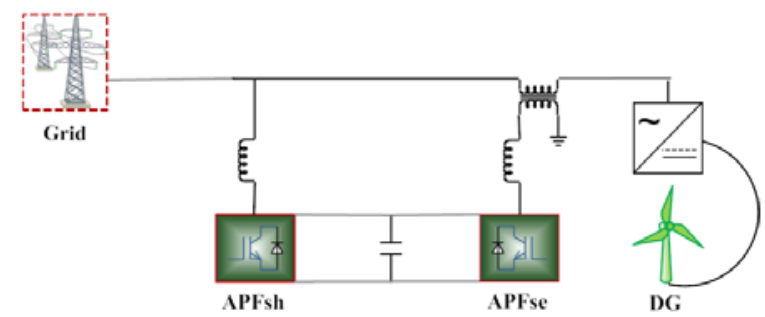

Figure 7 - Grid connected wind energy system with UPQC 
Khadem et al.: UPQC for DG Integrated Smart Grid Network - A Review
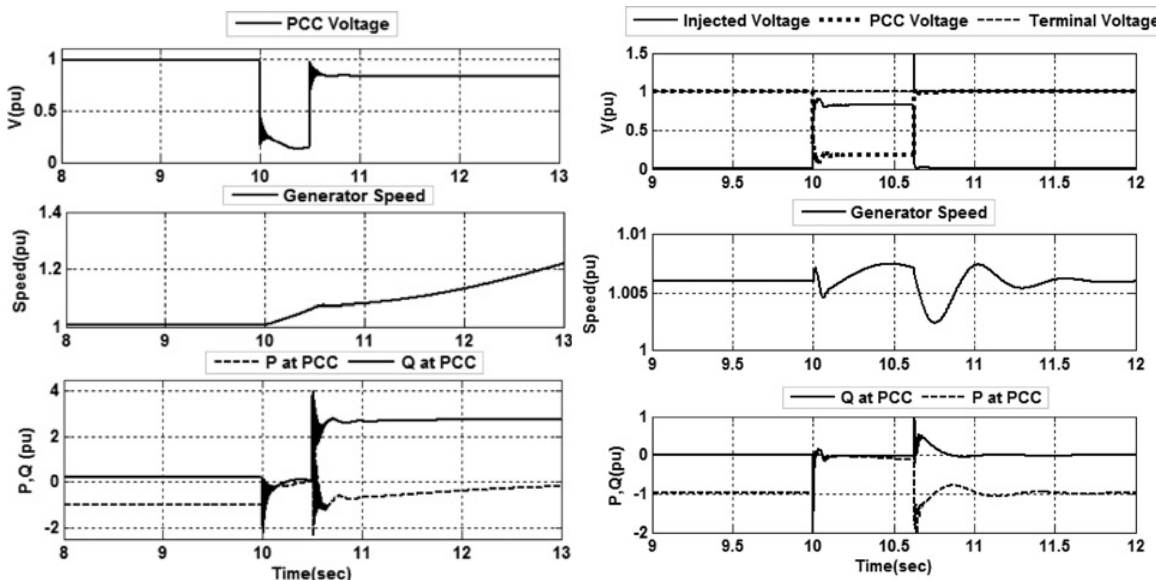

(a)

(b)

Figure 8- (a) Generator response to a three-phase fault without UPQC; (b) Generator response to a three-phase fault with UPQC [11]

Table 3 - Comparative analysis of integration techniques of UPQC in DG system

\begin{tabular}{|c|c|c|}
\hline Technique & Advantages & Disadvantages \\
\hline$(\mathrm{DG}-\mathrm{UPQC})_{\mathrm{DC}-\text { linked }}$ & $\begin{array}{l}\text { i. Compensate the voltage interruption } \\
\text { ii. Operation in islanding mode - } \\
\text { possible } \\
\text { iii. Active power transfer during grid } \\
\text { connected or microgrid mode - possible } \\
\text { iv. System cost for PQ improvement - } \\
\text { reduced (remove DG Inverter) }\end{array}$ & $\begin{array}{c}\text { i. Control complexity - high } \\
\text { ii. Capacity enhancement in } \\
\text { multi-level or multi-module } \\
\text { mode - difficult }\end{array}$ \\
\hline$(\mathrm{UPQC}-\mathrm{DG})_{\text {Separated }}$ & $\begin{array}{l}\text { i. Capacity enhancement in multi-level } \\
\text { or multi-module mode - easy } \\
\text { ii. Control - easy } \\
\text { iii. Active power transfer during grid } \\
\text { connected mode - possible }\end{array}$ & $\begin{array}{l}\text { i. Voltage interruption - may } \\
\text { not be possible } \\
\text { ii. Operation in islanding } \\
\text { mode - may not be possible } \\
\text { iii. System cost - high }\end{array}$ \\
\hline
\end{tabular}

\section{Cost Analysis}

In terms of required components, it is clear that the combined system does not require the grid connecting interfacing converter and thus the cost will be less. The purpose of the converter is already carried out by the shunt APF in the UPQC system. On the other hand in the separate system two complete units of UPQC and DG unit are required along with the interfacing converter. Therefore, there is no way to reduce the cost. A comparative analysis of investment cost and economical saving of separated and combined UPQC-DG (Wind Energy System) 
has been done in [8] based on the component cost found in [14]. It is found that, depending on the ratings, the combined system can reduce the cost up to one fifth of the separate system. Table 4 shows the details of this comparison.

Table 4 - Comparison of investment cost and economic saving (in USD) of separate and combined UPQC and DG (wind system) [8]

\begin{tabular}{|c|c|c|c|c|c|c|}
\hline \multirow[b]{3}{*}{ Equipment } & \multicolumn{6}{|c|}{ Rating (kVA) } \\
\hline & \multicolumn{2}{|l|}{15} & \multicolumn{2}{|l|}{150} & \multicolumn{2}{|l|}{1500} \\
\hline & Separate & Combined & Separate & Combined & Separate & Combined \\
\hline Wind turbine & 10515 & 10515 & 105004 & 105004 & 1050000 & 1050000 \\
\hline PWM rectifier & 5786 & 5786 & 47800 & 47800 & 394841 & 394841 \\
\hline Grid side inverter & 5786 & - & 47800 & - & 394841 & - \\
\hline Shunt inverter & 5786 & 5786 & 47800 & 47800 & 394841 & 394841 \\
\hline Series inverter & 5786 & 5786 & 47800 & 47800 & 394841 & 394841 \\
\hline Whole & 33662 & 27876 & 296202 & 248702 & 2629366 & 2234525 \\
\hline Economic saving $(\%)$ & 20.7 & & 19.1 & & 17.6 & \\
\hline
\end{tabular}

\section{UPQC IN DOUBLE FEEDER DISTRIBUTION SYSTEM}

A new connection proposal for UPQC, as shown in Figure 9, to improve the power quality of two feeders in a distribution system has been made in [15] which is termed Interline UPQC (IUPQC). The purpose of the IUPQC is to hold the feeder voltages constant against voltage sag/swell and temporary interruption in either of the two feeders. It has been demonstrated that the IUPQC can absorb power from one feeder to hold the other feeder voltage constant in case of a voltage sag in the other source voltage. This UPQC can also be implemented in a Custom Power Park or Microgrid system. This can further be improved as a multi-converter based UPQC [16] where multiple VSI are connected back to back on the dc side.

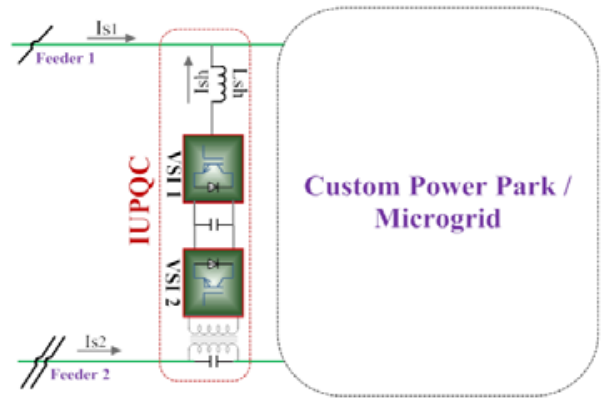

(a)

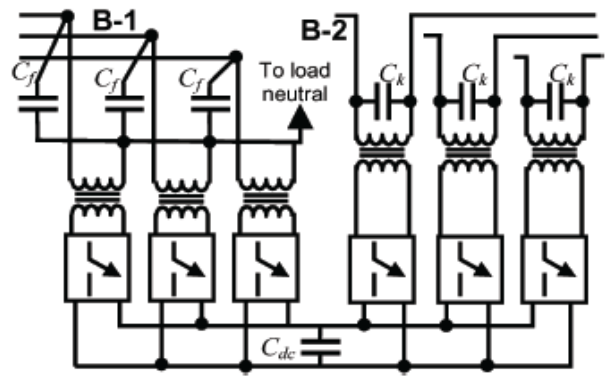

(b)

Fig 9 - (a) Typical IUPQC in a distribution system; (b) Internal Structure of IUPQC [15] 


\section{CAPACITY ENHANCEMENT OF UPQC}

In high power applications, the filtering task cannot be performed for the whole spectrum of harmonics by using a single converter due to the limitations on switching frequency and power rating of the semiconductor devices. Therefore, compensating the reactive harmonic components to improve the power quality of the DG integrated system as well as to avoid the large capacity centralised APF, parallel operation of multiple low power APF units are increasing. Like APF, UPQC can also be placed at the PCC or at a high voltage distribution line as a part of DG integrated network or in microgrid system to work both in interconnected or islanded mode. At this place, capacity enhancement is achieved by using Multilevel topologies to reach the higher power levels. These options are as follows:

i. Multi-level converter based UPQC

ii. Multi-module converter based UPQC

iii. Multi-module (power cell) unit based UPQC

A multi-level converter is proposed to increase the converter operation voltage, avoiding the series connection of switching elements. However, the multilevel converter is complex to form the output voltage and requires an excessive number of back-connection diodes or flying capacitors [17] or cascade converters [18]. A basic form of multi-level UPQC is shown in Figure 10.

A multi-module H-bridge UPQC can also be connected to the distribution system without series injection transformers. It has the flexibility in expanding the operation voltage by increasing the number of H-bridge modules [19], as shown in Figure 11. Here each phase consists of several pairs of H-bridge modules isolated through a single-phase multi-winding transformer.

These Multi-module techniques [17-22] allow the symmetrical distribution of the load power among the components of the topology, but the classical design procedure must be modified or refined to ensure the power cell components should be within its maximum ratings. Therefore, a new design procedure of UPQC with a feature of extending capacity based on a modular approach is presented in [23-24], shown in Figure 12, where H-bridge power cells are added in each single phase arrangement depending on the required compensating power. Some advantages and disadvantages are also outlined in Table 5. 
International Journal of Emerging Electric Power Systems, Vol. 13 [2012], Iss. 1, Art. 3

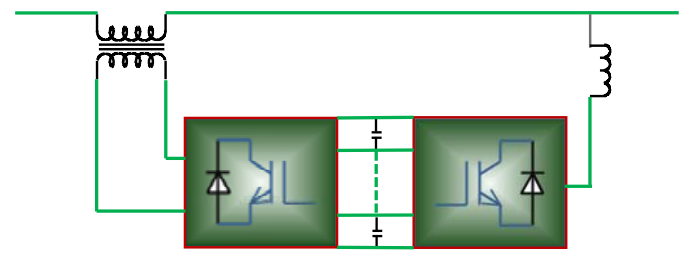

Figure 10 - Multi level Converter based UPQC

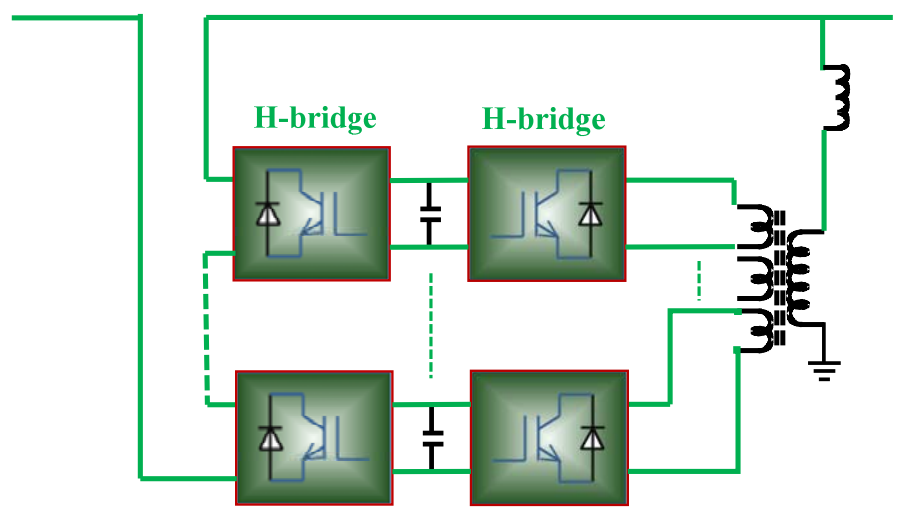

Figure 11 - Series transformer-less Multi-module H-bridge

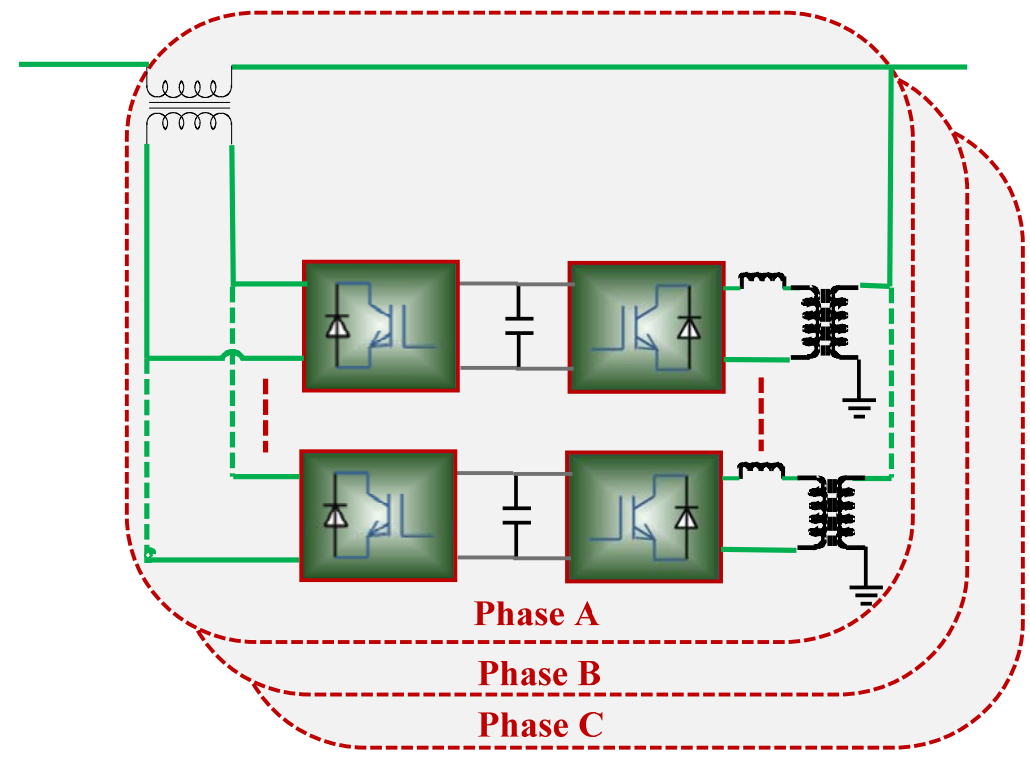

Figure 12 - Modular approach of UPQC based on power cells 
Khadem et al.: UPQC for DG Integrated Smart Grid Network - A Review

TABLE 5 - Advantages and disadvantages for different types of UPQC in capacity expansion.

\begin{tabular}{|c|c|c|}
\hline $\begin{array}{l}\text { Type of } \\
\text { UPQC }\end{array}$ & Advantages & Disadvantages \\
\hline $\begin{array}{l}\text { Multi-level } \\
\text { Converter } \\
\text { based }\end{array}$ & $\begin{array}{l}\text { i. High voltage and current can be } \\
\text { achieved } \\
\text { ii. Can be developed in different } \\
\text { ways - diode clamp / flying } \\
\text { capacitor / cascade inverter based }\end{array}$ & $\begin{array}{l}\text { i. Voltage unbalance could occur } \\
\text { between the different levels } \\
\text { ii. Requires accessive number of } \\
\text { diode / flying capacity / inverter } \\
\text { iii. Central control is required and it is } \\
\text { complicated } \\
\text { iv. Conduction loss is high } \\
\text { v. Capacity expansion is difficult } \\
\text { vi. Centralized Approach }\end{array}$ \\
\hline $\begin{array}{l}\text { Multi- } \\
\text { modular } \\
\text { transformer- } \\
\text { less }\end{array}$ & $\begin{array}{l}\text { i. No series transformer is } \\
\text { required, thus reduces the cost } \\
\text { ii. Capacity expansion is easier } \\
\text { than multi-level converter } \\
\text { iii. Redundancy is possible }\end{array}$ & $\begin{array}{l}\text { i. It requires high number of switching } \\
\text { devices to enhance the capacity } \\
\text { ii. Central control is required } \\
\text { iii. Conduction loss and switching loss } \\
\text { also high } \\
\text { iv. Due to symmetrical distribution of } \\
\text { the load power among the H-bridge } \\
\text { inverters, modules may not work at its } \\
\text { maximum rating }\end{array}$ \\
\hline $\begin{array}{l}\text { Multi- } \\
\text { modular } \\
\text { (power cell) }\end{array}$ & $\begin{array}{l}\text { i. Single phase power cell } \\
\text { topology helps the unit to work at } \\
\text { its maximum rating } \\
\text { ii. Capacity expansion is easier } \\
\text { iii. Redundancy is possible } \\
\text { iv. Both Central and Distributed } \\
\text { controls are possible } \\
\text { v. Due to parallel mode of } \\
\text { operation, conduction loss can be } \\
\text { reduced }\end{array}$ & $\begin{array}{l}\text { i. Number of H-bridge switching } \\
\text { device increases, thus increase the } \\
\text { switching loss } \\
\text { ii. Transformer for each shunt part of } \\
\text { the power cell could increase the loss } \\
\text { as well as make the system bulky } \\
\text { iii. Additional single shunt unit may } \\
\text { not be included if only the required } \\
\text { compensating current increases }\end{array}$ \\
\hline
\end{tabular}

\section{CONCLUSION}

It is found that research in recent years has placed more emphasis on CPDs, especially on UPQC, and its application in DG or microgrid system. Single or modular type UPQC has been proposed to deal with power quality issues, with an addition to voltage interruption compensation, active power transfer, related to DG with integrated or microgrid mode. Capacity enhancement has been achieved using multi-level or multi-module and central control mode, however, the flexibility of UPQC to increase its capacity in future and to cope up with the 
International Journal of Emerging Electric Power Systems, Vol. 13 [2012], Iss. 1, Art. 3

increase load demand in low voltage distribution level has not been achieved. The economics for the capacity enhancement of UPQC should also be analyzed.

\section{REFERENCES}

[1] P Jarventausta, S Repo, A Rautianinen, J Partanen, “Smart grid power system control in distributed generation environment", Annual Reviews in Control 34, 2010, pp. 277 - 286

[2] IEC Smart Grid Standardization Roadmap, http://www.iec.ch/smartgrid/downloads/sg3_roadmap.pdf

[3] NIST Smart Grid Conceptual model framework, http://smartgrid.ieee.org/smart-grid-framework-diagram

[4] B Han, B Bae, H Kim, S Baek, "Combined Operation of Unified Power Quality Conditioner with Distributed Generation”, IEEE Trans Power Delivery, vol. 21(1), 2006, pp. 330 - 338

[5] G S Reddy, "Feasibility analysis of DGSC-UPQC", Int Journal Research and Reviews in Applied Sciences, vol 4(1), 2010, pp. 32-47

[6] M Hosseinpour, Y M Rezapour, S Torabzade, “Combined operation of Unifier Power Quality Conditioner and Photovoltaic Array”, Journal of Applied Sciences, vol 9(4), 2009, pp 680-688

[7] M A Emran, M Forghani, M Abedi, G B Gharehpetian, "Combined Operation of UPQC and Fuel Cell with Common DC Bus”, Int Conf Renewable Energy and Power Quality, 2008

[8] M Hosseinpour, A Yazdian, M Hohamadian, J Kazempour, "Desing and Simulation of UPQC to Improve Power Quality and Transfer Wind Energy to Grid”, Jour of Applied Sciences, 2008, vol. 8(21), pp. 3770 - 3782.

[9] Council of European Energy Regulators, Electricity Working Group Quality of Supply Task Force, Third Benchmarking Report on Quality of Electricity Supply, Final Version, 2005. Available: http://www.energy-regulators.eu.

[10] H Akagi and K Nabae, Control strategy of active power filters using multiple voltage source PWM converters, IEEE Trans. Ind. Appl. vol. l (3), 1985, pp. 460-466

[11] N G Jayanti, M Basu, M. F. Conlon and K. Gaughan "Rating requirements of the unified power quality conditioner to integrate the fixed speed induction generator-type wind generation to the grid”, IET Renewable Power Generation, vol. 3(2), 2009, pp. 133-143

[12] M F Farias, P E Battaiotto, M G Cendoya, "Wind Farm to Weak-Grid connection using UPQC Custom Power Device”, Int Conf on Industrial Technology, 2010, pp. $1745-1750$ 
[13] A Ghosh and G Ledwich, "Power quality enhancement using custom power devices", Kluwer Academic, 2002.

[14] J K Kaldellis, K A Kavadias, "Cost-benefit analysis of remote hybrid winddiesel power stations: Case study Aegean Sea Islands”, Energy Policy, vol 35, 2007, pp. 1525-1538

[15] A Kumar, “A Ghosh, Interline Unified Power Quality Conditioner”, IEEE Trans Power Delivery, Vol. 22(1), 2007, pp. 364-372.

[16] H R Mohammadi, A Y Varjani, "Multiconverter Unified Power-Quality Conditioning System: MC-UPQC”, IEEE Trans Power Delivery, Vol. 24(3), 2009, pp. 1679-1686.

[17] J Lai, F Z Peng, “Multilevel converters-a new breed of power converters”, IEEE Trans Ind Appl, Vol. 32(3), 1996, pp. 509 - 517

[18] F Z Peng, J W McKeever and D J Adams, "A Power Line Conditioner Using Cascade Multilevel Inverters for Distribution Systems”, IEEE Trans Ind Appl, Vol 34(6), 1998, pp. 1293 - 1298

[19] B. Han, B. Bae, S. Baek and G. Jang, "New Configuration of UPQC for Medium-Voltage Application”, IEEE Trans Power Delivery, Vol. 21(3), 2006, pp. $1438-1444$

[20] B. Han, S. Baek, H. Kim, and G. Karady, "Dynamic characteristic analysis of SSSC based on multibridge inverter," IEEE Trans. Power Del. Vol. 17(2), 2002, pp. 623-629

[21] B.-M. Han and P. Mattavelli, "Operation analysis of novel UPFC based on 3level half-bridge modules,” in Proc. IEEE Bologna Power Tech Conf., Jun. 2003, vol. 4, pp. 307-312.

[22] J. Muñoz, J. Reyes, J. Espinoza, I. Rubilar, and L. Morán, “A novel multilevel three-phase UPQC topology based on full-bridge single-phase cells," in Proc. Conf. Rec. IEEE IECON, Nov. 2007, pp. 1787-1792.

[23] J A Munoz, J R Espinoza, "Design of a Modular UPQC Configuration Integrating a Components Economical Analysis", IEEE Trans Power Delivery, Vol. 24(4), 2009, pp. 1763-1772.

[24] J A Muñoz, J R Espinoza, C R A Morán, E Espinosa, P E Melín, D G Sbárbaro, "Design of a Discrete-Time Linear Control Strategy for a MultiCell UPQC”, accepted for publication in IEEE Trans Ind Electr, 2011 